\title{
Reference to Shari'ah Advisory Council in Islamic finance: Effect of Changes to the Stakeholders
}

\author{
Nurauliani Jamlus Rafdi ${ }^{\text {a, } 1}$, Surianom Miskam ${ }^{\text {b, } 2}$, Noor Aimi Mohamad Puad ${ }^{\text {a, } 3}$ \\ Faculty of Management and Muamalah \\ Kolej Universiti Islam Antarabangsa Selangor (KUIS) \\ Bandar Seri Putra, Kajang \\ Malaysia \\ ${ }^{1}$ nurauliani@kuis.edu.my, ${ }^{2}$ surianom@ @uis.edu.my, ${ }^{3}$ nooraimi@ @uis.edu.my
}

\begin{abstract}
The passing of the Central Bank of Malaysia Act 2009 has granted the authority to the Central Bank of Malaysia for the establishment of the Shariah Advisory Council as the highest and sole authority for the purpose of Islamic financial business in Malaysia. The intention of the Parliament is to rectify the defunct provision of Section 16B of the Central Bank of Malaysia 1958 which deals with the binding effect of the Shariah rulings issued by the Shariah Advisory Council. The effect of the Central Bank of Malaysia Act 2009 is yet to be discussed especially on the impact of changes in the Act to the stakeholders. The objective of this research is to analyse the impact of changes on the stakeholders namely the Shariah Committee of Islamic banks and bankers from operation division in Islamic banks. Qualitative research methodology is employed in this research by way of strategic conversation and focus group discussion. This research will provide a critical analysis and expected to give a clear explanation on the impact of changes in the Central Bank of Malaysia Act 2009 towards the stakeholders.
\end{abstract}

Keywords: Shariah Advisory Council, Islamic Finance, impact, stakeholders.

\section{Introduction}

The Malaysian government has taken a further step in enhancing the framework of Shari'ah governance in Islamic finance with the introduction of the Central Bank of Malaysia Act 2009 (CBA 2009). This new legislation was passed by the Parliament in July 2009 which received royal assent on 19th August and gazetted on 3rd September 2009. The Act came into effect on 25 November 2009 and consists of 100 sections divided into 15 parts. Unlike the Central Bank of Malaysia Act 1958 (CBA 1958), the CBA 2009 inserts new provision in Part VII which covers provision pertaining to Islamic financial business.

The CBA 2009 has granted the authority to the CBM for the establishment of the SAC as the highest and sole authority for the purpose of Islamic financial business in Malaysia. The intention of the Parliament is to rectify the defunct provision of Section 16B of the Central Bank of Malaysia 1958 which deals with the binding effect of the Shari'ah rulings issued by the SAC. The effect of the CBA 2009 on the stakeholders is yet to be discussed in length in any studies

\section{Literature Review}

Reference to Shari'ah Advisory Board in Islamic Finance: The practice around the globe

Shari'ah supervision or Shari'ah advisory play an essential role in the governance of Islamic financial institution and forms part of the principal component of the Shari'ah governance framework (Hamza, 2013). One of the roles of the Shari'ah supervisory board is to advise the Islamic financial instutions on Shari'ah matters to ensure conformity with Shari'ah rule in its operations at all time, endorsing and validating relevant documentations pertaining to the products and services of the Islamic financial institutions. The ideal role of Shari'ah supervision involve ex ante and ex post aspects of Shari'ah governance and these include Shari'ah pronouncement, supervision and review. (Zulkifli, 2011)

In this aspect, the Shari'ah governance framework in Malaysia is based on the centralised model as compared to the decentralized being practiced in the GCC countries (Hamza, 2013).The centralised model is formed on the basis that the Central Bank itself has its own Shari'ah supervisory board called the SAC by virtue of section 51 of the CBA 2009 and all Islamic financial institutions are required to form their own Shari'ah committee which must comply with the rules set by the SAC of the CBM.

The importance of Shari'ah supervision is derived from five different resources namely religious, social, economic, legal and governance. The religious position is derived from the ability of Shari'ah scholars in understanding and interpreting Shari'ah principles to others. The social power of the Shari'ah supervision provides confidence to the stakeholders about the legitimacy of the transactions and activities of the Islamic financial institutions 
The risk of Shari'ah incompliance may have serious consequences on the continuity of the activities of the Islamic financial institutions in particular and the development of the Islamic financial system in general. This is due to the fact that Islamic finance is based on Shari'ah law and all Islamic financial institutions' activities must be compliant with Islamic rules and principles Based on this premise, the need for an efficient Shari'ah supervisory system is considered as one of the vital element promoting the stability of the Islamic financial sector. With this aspiration, corporate governance in Islamic financial institutions has to set institutional arrangements to supervise the Shari'ah-compliant aspects of their activities. (Rihab Grassa, 2013)

\section{Reference to Shari'ah Advisory Council in Islamic Finance: The legal framework in Malaysia}

The establishment of SAC in Islamic Finance was first statutorily provided by the amendment to the CBA 1958 in 2003 to insert section 16B which provides for the establishment of an Advisory Council which shall be the authority for the ascertainment of Islamic law for the purposes of Islamic banking business, takaful business, Islamic financial business, Islamic development financial business, or any other business which is based on Shari'ah principles and is supervised and regulated by the CBM.

The 2003 amendment was passed with the objective to provide better position on the National SAC whereby it uplifts the position of Islamic banking and finance in Malaysia. It should be noted that an Islamic bank may also seek the advice of the SAC on Shari'ah matters relating to its banking business and the Islamic bank shall comply with the advice of the SAC by virtue of section 13A of the IBA 1983 and it is mandatory for the Islamic banks to comply with the advice given by the SAC pursuant to such request. (Engku Rabiah, 2008).

Section 16B CBA 1958 expressly stated that where in any proceedings relating to Islamic banking business and Islamic financial business which is based on Shari'ah principles before any court or arbitrator any questions arises concerning a Shari'ah matter, the court or the arbitrator may refer such question to the SAC for its ruling. Any ruling made by the SAC pursuant to a reference by a court, be taken into consideration by the court and if the reference was made by an arbitrator, be binding on the arbitrator.

Before the coming into force of the CBA 2009, the SAC has always been considered as an authoritative body with the expertise and competency to provide ruling on Islamic finance issues. According to Ruzian \& Noor Inayah (2012) the presiding judge is not precluded from exercising his own discretionary power and has the option whether to refer the issue to the SAC.

Reference to the law reports shows that the civil courts have in fact referred to section $16 \mathrm{~B}$ and acknowledged the requirement of the provision but elected not to refer to the SAC on the ground that the ruling made by the Council has no binding effect on them.

The legislature had taken step to rectify the above situations by passing the CBA 2009 and it is done by granting the authority to the CBM for the establishment of the SAC as the highest and sole authority to be referred by the civil courts in dealing with Islamic banking and finance cases in Malaysia. The law is intended to further enhance and improve the Shari'ah governance framework in Islamic financial system with special reference to the establishment of the SAC, its functions, method of appointment, qualification and criteria of the members and the status of Shari'ah rulings issued by the SAC under the law.

The CBA 2009 further provides that any ruling made by the SAC pursuant to a reference made under Chapter VII shall be binding on the Islamic financial institutions and the court or arbitrator dealing with Islamic banking cases. (Ahmad Suhaimi, 2009). The provision clearly states that any ruling made by the SAC will be binding on the civil court and the arbitrator which means the court and the arbitrator must follow the ruling to arrive at their decision and the ruling shall form part of the judgment of the court in Islamic finance cases. (Tengku Hasmuddin, 2009).

Ruzian and Noor Inayah (2012) opined that although the new law upholds and binds the parties to the rulings of the SAC, the judges still have the discretionary power and they do not rely solely on the rulings of the SAC but they must decide based on their own understanding of the principles of maslahah and the role of masalah to make sure fair outcome of the case.

Adnan Trakic (2013) conluded that by virtue of sections 56 and 57 of the CBA 2009, the civil court judges or arbitrators dealing with cases arisng from Islamic financial business are obliged to refer Shari'ah issues to the SAC for ruling and its ruling becomes binding on them. He observed that he efficacy and workability of this model has already been tested in a few judicial decisions in Malaysia.

\section{Effects of the law towards the stakeholders}

The effect of the CBA 2009 on the stakeholders is yet to be discussed in length in any studies. According to Asyraf Wajdi Dusuki (2008), the study of stakeholders' perceptions towards Islamic banking in Malaysian context is far more 
crucial, mainly due to the fact that Islamic banks have to compete with the long established interest-based conventional banks in a dual-banking system. This is because the bulk of literature on Islamic banking is focusing only on commercial and economic aspects of Islamic banking, while social issues pertaining to its practices are normally relegated to the back seat in the discussion. At this point, the legal issues pertaining to its practices are confined to the policy and implementation aspects of the law but not the effects of the law to various stakeholders.

The stakeholders of Islamic banks according to Asyraf Wajdi (2008) are customers, depositors, managers, employees, Shari'ah advisors, regulators and local communities. Muslim Amin, et al (2013) suggested that that Muslim customers establish relationships with Islamic banks because they trust that Islamic banks are Shari'ah compliant. Therefore, providing secure banking products that are fully compliant with Islamic principles are necessary in order to create and maintain relationship with customers. Thus in order to ensure that the aims and operations of Islamic banks are Shari'ah compliant, the role of the SAC is essential to this effect.

Hafij Ullah (2014) found that on an average 76.05 per cent strongly agreed and 22.16 per cent of the Islamic bank employees in Bangladesh agreed that Islamic bank provide first priority is Shari'ah compliance in performing all transactions of the Islamic banks. However, he concluded that government rules and regulations, Bangladesh Bank's rules and regulations and interest-based economy of Bangladesh are impediments to Shari'ah compliance by the Islamic banks in Bangladesh.

\section{Methodology}

The objective of this research is to analyse the impact of changes on the stakeholders namely the Shariah Committee of Islamic banks and bankers from operation division in Islamic banks

Qualitative research methodology is employed in this research by way of strategic conversation and focus group discussion. Strategic conversation is an approach where the selected Shari'ah Committee members of Islamic banks will be interviewed to get their view on the changes of CBA 2009. The strategic conversation will help the researcher to have an idea on the changes and effect on the provision of the CBA 2009. This will reflect the effect before the changes made and after the changes has been made.

The respondents were the Shari'ah Committee (SC) of the Islamic banks. Structured questionnaire were designed to get the feedback on the impact of changes in Act from the perspective of SC as the Shari'ah advisors for the respected Islamic bank.

Focus Group Discussion provides perceptions, opinions, beliefs and attitudes towards certain issues. A Focus Group discussion produces data and insights that will be less accessible without interactions. In this research Focus Group Discussion will be conducted for the representative from selected Islamic Banks. The discussion will provide insights on the effect of changes in the CBA 2009 from the perspective of banking practitioners.

Six respondents participated in the focus group discussion, from various Islamic banks, namely Bank Islam Malaysia Berhad, Hong Leong Islamic Bank, CIMB Islamic Bank, RHB Islamic Bank, Agro Bank and Bank Rakyat. The representatives were from the operation side of the Islamic banks and most of them were working in the banking sector from minimum 2 years up to 26 years. The discussion was moderated by the researcher.

Based on the strategic conversation and focus group discussion, two separate SWOT analysis was done to support the analysis.

\section{Analysis and Discussions \\ Effect of the Act changes towards SC Members}

The members of Shari'ah Committee (SC) are the scholars with knowledge and expertise in Islamic jurisprudence. The ultimate purpose of the establishment of the SC in Islamic financial institutions is to ensure Shari'ah compliance to its operations and products. All banks and takaful operators must have provision regarding the establishment of SC in their Articles of Association and Memorandum of Association. The term Shari'ah Cmmittee has been introduced by CBM in section 3 of the Guidelines and Procedures for Shari'ah Committee (BNM/GPS1) issued in December 2004.

The main duties of SC members are as followings:

i. The SC will evaluate the concept and structure of the new product and will review the existing products.

ii. The SC will vet meticulously and endorse all documents involved and these include the terms and conditions contained in the proposal form, contract, and agreement or other legal documentation used in executing the transactions; and the product manual, marketing advertisements, sales illustrations and brochures used to describe the product.

iii. The $\mathrm{SC}$ will monitor the Islamic banking operations from time to time.

iv. The related parties of Islamic financial institution such as its legal counsel, auditor or consultant, branches or 
even customer may seek advice on Shari'ah matters from the SC.

v. Section 20 (f) of BNM/GPS 1 requires the SC to record any opinion given. In particular, the Committee through its secretariat shall prepare written Shari'ah opinions where Islamic financial institution makes reference to the SAC for advice.

vi. Section 20 (b) of BNM/GPS 1 states that the manual will specify the manner in which a submission or request for advice be made to the $\mathrm{SC}$, the conduct of the SC's meeting and the manner of compliance with any Shari'ah decision.

vii. Section 20 (e) of BNM/GPS 1 requires the SC to assist the SAC of CBM on any matters referred by Islamic financial institution.

viii. SC deal with certain general duties and tasks relevant to their job scope and this includes to assist the related parties on Shari'ah matter and to determine the zakah policy of the banks.

The BNM/GPS1 has been replaced by the "Shari'ah Governance Framework for Islamic Financial Institutions" (SGF 2010), with the objectives of ensuring Shari'ah compliance by Islamic financial institutions, instilling public confidence in Islamic banking, and promoting financial stability at the domestic level.

SGF 2010 was adopted pursuant to Section 59 of the CBA to enhance the role of the Board, the SC and the management in relation to Shari'ah matters, which includes enhancing the relevant key organs that are responsible for executing Shariaah compliance and research functions aimed at the attainment of a Shari'ah based operating environment.

This Shari'ah Governance Framework for Islamic Finance was later statutorily recognised with the introduction of the Islamic Financial Services Act 2013 (IFSA 2013) which came into force on 30 June 2013. The IFSA was intended to pave way for the development of an end-to-end Shari'ah compliant regulatory framework for the conduct of Islamic financial operation in Malaysia. Prior to 30 June 2013, the legal framework relating to Shari'ah governance in Islamic finance was not statutorily provided.

The provision relating to Shari'ah governance is one of the major features being introduced under the IFSA 2013 which contributes to the boost of authorities as well as roles of the Shari'ah Committee, thus ensuring the activities of the Islamic financial institution to be under Shari'ah compliance thus maintaining a sound and robust Shari'ah governance framework in Islamic financial industry in Malaysia.

\section{Analysis of strategic conversation with Shari'ah Committee}

Strategic conversation was conducted with the identified SC to collect information on the effect of Act. Questions related to the study were designed to aid the information collection.

According to the SC members, generally they agree with the changes made in the CBA 2009. According to them, the changes will bring a positive impact towards the Islamic Finance industry in the long term. The CBA 2009 standardised the process in Islamic Banks all over Malaysia. This will reduce the burden of CBM to monitor all the Islamic banks in Malaysia.

Normally, the decisions made by the SC are tailored with the interest of the banks, however after the introduction of the CBA 2009, any decisions requires the SC members to get approval from the SAC. This creates a situation where the $\mathrm{SC}$ is no longer tied up with the interest of the banks. Generally, according to the representative of SC, the changes of Act, somehow has reduced their burden in terms of responsibilities that they have to carry. Sometimes the SC members do get pressures from the management; however, they still have the independence in following the requirements of the management since the approval is from the SAC.

There are some challenges faced by the SC when the CBA 2009 were enforced. The major challenges are faced by the Islamic bank that has branches in other countries. The decision made by the SAC sometimes does not harmonise with other countries, especially in Middle East. One of the examples of product that creates conflicting views is Bai Inah. This will give effect in promoting Malaysian market in Middle East. Any decision made by the SAC should harmonise with the requirement of Middle East to protect Malaysian market. Since the harmonisation is very important, there is a need for revisiting certain policies that creates controversy in the international market.

At the end of the strategic conversation, the representative of $\mathrm{SC}$ concluded that the changes of Act give a positive impact to the development of Islamic Finance in Malaysia. Almost all the Islamic Banks try to comply with the requirement of Act because of the strict enforcement by the CBM.

SWOT analysis for Shari'ah Committee part is provided in Table 1. 


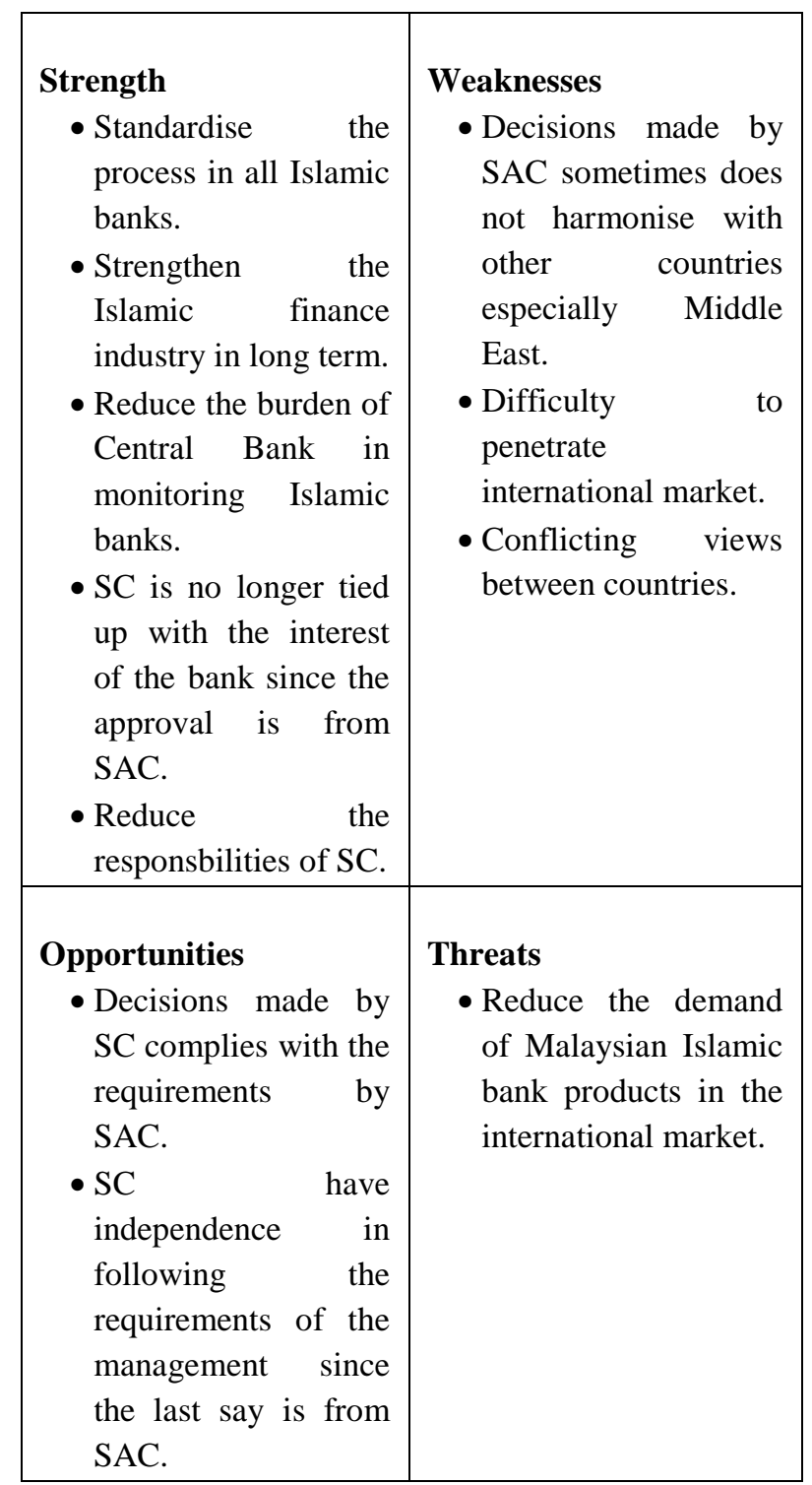

Table 1 : SWOT Analysis for Shari'ah Committee

\section{Effect of Act changes towards the employees of Islamic banks}

Focus group discussion was conducted to get the ideas of the operation staffs from Islamic banks relating to the changes of the Act. Six representatives from various Islamic banks with experience from 2 to 26 years in the operation division took part in the focus group discussion. The discussion was moderated by a member of the research team and the discussion was held for two hours. The moderator briefly explained the purpose of the discussion to the participants before starting the session.

Most of the participants were well-verse on the provisions of the Act and aware of the 2009 amendment to the Act. Generally the participants positively accept the Act introduced by the CBM realising on the importance of the Act in current situation. One of the participants mentioned that this Act was introduced to deal with the rising number of cases involving Islamic banks in the Malaysian courts. This Act is very important for the sustainability of the Islamic financial system in Malaysia and for long term the changes of Act is worthy for Islamic finance industry. In addition, another participant stressed that the Act recognises Islamic banking as a system in Malaysia.

Interestingly, when the question relating to the effect of the Act from the operation side, the feedback was different based on the level of experience of the participants. One of the issues raised by the participants is the time frame given by the CBM to implement the requirements of the Act. This created dissatisfaction among the operation staffs since they have to familiarise themselves with the Act in a very short period of time. The junior officer has different perception compared to the senior officers. According to junior officer in the focus group discussion who has 2 year experience claimed that the front office need to face a lot of difficulties especially in dealing with and explaining to the customers relating to the changes of Act. The junior officer also claimed that the management constantly push the burden to the front office staffs. However, this statement created arguments among the junior and senior participants.

The senior participants have a different point of view where for them managing people should be the expertise of the staffs and normally the CBM has the guidelines for the changes introduced. The junior participant further claimed that the guideline introduced by the CBM is quite technical and difficult to explain in the layman term to the customers. This is due to the incompetency of staffs in Islamic banks. The main constraint of most Islamic banks is the human capital issue where it is quite difficult to employ staffs who have good English communication and excellent Shari'ah knowledge. Responding to the issue of incompetency of staffs in Islamic banks, one of the senior participants pointed out that the incompetency issue need to be addressed by the management.

Majority of the senior participants agreed that all employers regardless of their positions are responsible for the implementation of the Act in the respective Islamic banks. Any fault by the operation division, the impact is towards the management. The operation staffs that are not able to answer certain questions relating to the Act to the customers can refer to the higher management for clarification. It is the responsibility of the management to clarify any ambiguities to the customers. Most of the customers who have this kind of difficulties are those who do not have knowledge in 
Islamic finance and they are not aware of current changes in Islamic finance.

The discussion also focuses on determining the similarities of challenges faced by all Islamic banks in Malaysia. One of the participants responded that, Islamic Banks have to face huge challenges when they are the subsidiary of a conventional bank. This is due to the fact that they have to promote conventional banking products together with Islamic banking products. Furthermore, the Islamic banks are utilising the staffs from the conventional banks sharing the same infrastructure. It creates conflict of interest between Islamic and conventional banks since they have different principles.

At the end of the session, the moderator requested for suggestions and recommendations in order to enhance and improve the implementation of the Act. One of the major action need to be taken is to have full-pledged Islamic banks without the involvement of the conventional banks. The education system also needs to be enhanced to tailor with the Islamic finance industry. This also includes an effective training by the banks to equip the staffs with the necessary knowledge and skills.

It is understood that the terms used by the Islamic banks are quite technical, to resolve this issue, the bank should simplify the Standard Operating Procedure and documentations for the convenience of the customers.

SWOT Analysis for bank employees is summarised in Table 2.

\section{Table 2: SWOT Analysis for Bank Employees}

\begin{tabular}{|c|c|}
\hline $\begin{array}{l}\text { Strength } \\
\text { - Help to sustain Islamic } \\
\text { financial system in } \\
\text { Malaysia. } \\
\text { - Standardisation of } \\
\text { documentation } \\
\text { involved in Islamic } \\
\text { banking products. } \\
\text { - The staffs have } \\
\text { knowledge both in } \\
\text { Islamic and } \\
\text { conventional banking } \\
\text { products. }\end{array}$ & $\begin{array}{l}\text { Weaknesses } \\
\text { - Lack of knowledge } \\
\text { and training among } \\
\text { employees of Islamic } \\
\text { banks. } \\
\text { - Short time frame } \\
\text { given to comply with } \\
\text { the requirements. } \\
\text { - Increase the burden of } \\
\text { front office staffs. } \\
\text { - Guidelines issued by } \\
\text { Central Bank are quite } \\
\text { technical. }\end{array}$ \\
\hline $\begin{array}{l}\text { Opportunities } \\
\text { - The staffs will be }\end{array}$ & $\begin{array}{l}\text { Threats } \\
\text { - Tendency of staffs }\end{array}$ \\
\hline
\end{tabular}

\begin{tabular}{|l|l|}
\hline $\begin{array}{l}\text { trained to be well verse } \\
\text { with requirements of } \\
\text { the Act. }\end{array}$ & $\begin{array}{l}\text { to promote } \\
\text { conventional } \\
\text { banking products are } \\
\text { higher since it is }\end{array}$ \\
- Mobilisation of & $\begin{array}{l}\text { easier to explain } \\
\text { Islamic bank staffs } \\
\text { from one Islamic bank } \\
\text { to another. }\end{array}$ \\
& $\begin{array}{l}\text { compared to Islamic } \\
\text { banking products. }\end{array}$ \\
\hline
\end{tabular}

\section{Conclusions}

Stakeholders are important in any organisation including financial institutions. In the context of Islamic banking the three important identified stakholders are Shari'ah Committee, employees of the bank and consumers. Any changes in the Act or policy will give direct impact towards these stakeholders.

The changes of Act, generally gives positive impact to all the stakeholders. SC member feels that their burden has been reduced when the highest authority for approval was vested on the SAC. It also reduces the level of responsbility that the SC member needs to carry.

In term of operation staffs, they are aware of the benefit of the changes to the Act, however, they feel the burden when the implimentation is in limited time. The staffs are lack of training and they need a time duration to be well versed with the procedures introduced by the CBM. They also claim that the guidelines provided by the CBM are technical and this creates difficulty for them to explain to the consumers. One of the opportunities when there is standardisation of procedures is the mobilisation of workers. The possibilities for the workers in one bank to another bank is high.

The changes of Act enable the CBM to monitor all the Islamic banks in Malaysia and protects the rights of the consumers. The standardisation process will help in sustaining the Islamic finance industry in the long term. The benefit covers all the stakeholders in Islamic finance system.

\section{Recommendations and Future Research}

The Islamic banks are responsible to simplify the technical documents provided by the Central Bank. Usually the guideline provided by the CBM to the Islamic banks are quite technical. It creates difficulties when the management of the Islamic banks request the operation staff to understand the document and explain to the consumers. The operation staff face problem to explain in a layman term to the consumers. Sometimes the information provided by the operation staff to consumers are vague. In order to resolve these issue, there is a need for Islamic banks in Malaysia to provide a simplified version of documentation. 
The management of Islamic banks need to provide proper and quality trainings to the staffs in order to equip them with necessary knowledge and skills. This will help them in explaining certain procedures to the consumers. A good communication skills and ability to explain will convince the consumer to maintain the relationship with the bank.

Awareness program is very crucial for the Islamic banks consumers especially relating to the procedures. The awareness program will enhance the customer knowledge and reduces the burden of the bankers to explain. It encourages the customer to explore and to understand further any requirements of Islamic banks.

Harmonisation of decision by SAC with other countries are important to the Islamic banks that has branches in other countries. The contradiction views will effect the business of Malaysian Islamic banks in other countries. It is important for the SAC to take into consideration the views of other countries, especially middle east in making any decisions.

Future research should also include the members of Shari'ah Authority Council (SAC) as one of the stakeholders in order to look at the impact from the view of policy makers.

\section{References}

Adnan Trakic (2013). The adjudication of Shari'ah issues in Islamic financial Contracts: Is Malaysian Islamic finance litigation a solution?. Humanomics Vol. 29 No. 4, 2013 pp. 260-275

Ahmad Suhaimi, Y. (2009). Isu-isu Shari'ah Dalam Menjadikan Perundangan Sivil sebagai Rujukan bagi Kewangan Islam.

Asyraf Wajdi Dusuki, (2008),"Understanding the objectives of Islamic banking: a survey of stakeholders' perspectives", International Journal of Islamic and Middle Eastern Finance and Management, Vol. 1 ISS 2 pp. 132 - 148

Engku Rabiah Adawiah, E.A (2008), Constraints and Opportunities in Harmonisation Of Civil Law And Shari'ah In The Islamic Financial Services Industry, Malayan Law Journal, [2008] 4 MLJ i; [2008] 4 MLJA 1.

Engku Rabiah Adawiyah, EA. (2009). Isu-isu Perundangan dan Kehakiman dalam Kewangan Islam.

Hafij Ullah , (2014),"Shari'ah compliance in Islamic banking", International Journal of Islamic and Middle Eastern Finance and Management, Vol. 7 Iss 2 pp. 182 - 199 Hakimah, Y. (2010). The new Central Bank of Malaysia Act 2009 (Act 701): Enhancing the Integrity and Role of the Shari'ah Advisory Council (SAC) in Islamic Finance. ISRA Research Paper. No 6/2010.

Hall, A.M. (2008). Systematic Content Analysis of Judicial Opinions. California Law Review.Vol 96: pp1-24.

Hichem Hamza (2013). Sharia governance in Islamic banks: effectiveness and supervision model. International Journal of
Islamic and Middle Eastern Finance and Management, Vol. 6 No. 3, 2013 pp. 226-237

Muslim Amin, Zaidi Isa \& Rodrigue Fontaine (2013). Islamic banks: Contrasting the drivers of customer satisfaction on image, trust, and loyalty of Muslim and nonMuslim customers in Malaysia. International Journal of Bank Marketing, Vol. 31 No. 2, 2013 pp. 79-97

Rihab Grassa (2013) Shari'ah supervisory system in Islamic financial institutions New issues and challenges: a comparative analysis between Southeast Asia models and GCC models. Humanomics Vol. 29 No. 4, 2013 pp. 333-348 Ruzian, M and Noor Inayah, Y. (2012). Litigation as Dispute Resolution Mechanism in Islamic finance: Malaysian experience. European Journal of Law and Economics

Ruzian, M. (2011). Adjudication of Islamic Banking and Finance Cases in the Civil Courts of Malaysia. European Journal of Law and Economics.

Tengku Hasmuddin, T.O.( 2009). Isu-isu Perundangan Dalam Kewangan Islam.

Tun Abdul Hamid Mohamed (2012). Issues And Challenges Pertaining To The Role Of Shari'ah Advisory Council In Upholding Shari'ah Principles In Islamic Banking And Finance [2012] 8 CLJ i

Zulkifli, H. and Mehmet, A. (2011). An Analysis of the Court's Decisions on Islamic Finance Disputes. ISRA International Journal of Islamic Finance, Vol 3 Issue 2, 4161

\section{Acknowledgement}

This research is under the Research Grant from Kolej Universiti Islam Antarabangsa Selangor (KUIS) from 1 April 2014 until 31 Mac 2015. We thank the University for the financial assistance awarded to complete this research. 